Antonio Vlahov, Ph.D.

University of Zagreb, Faculty of Economics and Business, Zagreb, Croatia avlahov@efzg.hr

Dominik Vuletić, Ph.D.

University of Zagreb, Faculty of Economics and Business, Zagreb, Croatia dvuletic@efzg.hr

\title{
REVISION OF THE PACKAGE TRAVEL DIRECTIVE AND ITS INFLUENCE ON THE CROATIAN TOURSIM LAW
}

Received: October 15, 2018

Accepted: December 25, 2018

\section{Preliminary communication}

\begin{abstract}
The paper explores normative substance of the new Package Travel Directive (2015/2302/EU) and its influence on the Croatian Tourism Law. The new Directive was adopted on 25 November 2015, European Union Member States had to transpose it by 1 January 2018 and it is applicable from 1 July 2018. Internet as increasingly important medium for travel services resulted in surge of various forms of customized travel arrangements and rendered provisions of the old Directive obsolete to the needs modern tourist market. Although 23\% of EU travellers still purchase traditional, pre-arranged packages, more and more either buy different parts of their trips separately or buy customized holidays, which are put together by one or more commercially linked traders to suit their needs and preferences. Vast majority of travellers buying packages and linked travel arrangements are consumers within the meaning of the EU Consumer Protection Law. Thus, new Package Travel Directive should result in the enhancement of the consumer protection. New legislation will extend protection of the of the $1990 \mathrm{EU}$ Package Travel Directive to cover not only traditional package holidays, but also give clear protection to 120 million consumers who book other forms of combined travel. Scope of the new Package Travel Directive is substantially wider than the scope of the old Directive. The new Package Travel Directive applies to packages offered for sale or sold by traders to travellers and to linked travel arrangements facilitated by traders for travellers. The new Directive broadens the concept of package and now will apply to different sorts of travel combinations: pre-arranged packages; customised packages and linked travel arrangements. This paper elaborates on normative and substantive influence of the new Directive in Croatian Tourism Law. Following comparative legal overview current Croatian legislation
\end{abstract}


of package travel including applicable sections of the Civil Obligations Act will be inspected.

Keywords: package travel Directive, Croatian tourism law, civil obligations, EU Law

JEL: K2

\section{INTRODUCTION}

The new Package Travel Directive (2015/2302/EU) ${ }^{1}$ was adopted on 25 November 2015 with aim of updating EU acquis with the developments in the travel market. The new Directive once when transposition period expires will replace old Directive 90/314/EC of 13 June 1990.

Internet as increasingly important medium for travel services caused surge of various new forms of customized travel arrangements. Majority of new forms fall outside the scope of traditional pre-arranged packages covered by the old Directive. Therefore need for regulating increasing range of grey zones in the matters of travel arrangement influenced EU legislator to intervene and revise existing legislation. Increasing the consumer protection of tourists was one of the key motivators or ratio legis. Obviously, vast majority of travellers buying packages and travel arrangements are consumers within the meaning of the EU Consumer Protection Law.

The EU internal market, imagined by the Treaty on Function of the EU (TFEU) as the area without internal frontiers in which the free movement of goods and services and the freedom of establishment are ensured, in the field of travel arrangements becomes more and more integrated due to the new technological developments. The EU decided with the new Package Travel Directive to construct formal and normative framework to facilitate this somewhat spontaneous and informal process. The new Directive broadens the concept of package and now will apply to different sorts of travel combinations: pre-arranged packages; customised packages and linked travel arrangements.

The new Package Travel Directive increases level of harmonization in comparison with the minimum harmonization of the old Directive. Once when transposition period for the new Directive expires on January $1^{\text {st }} 2018$ Member states of the EU

\footnotetext{
${ }^{1}$ Full name of the new Package Travel Directive is: Directive (EU) 2015/2302 of the European Parliament and of the Council of 25 November 2015 on package travel and linked travel arrangements, amending Regulation (EC) No 2006/2004 and Directive 2011/83/EU of the European Parliament and of the Council and repealing Council Directive 90/314/EEC
} 
should have more harmonized rules on this subject matter. We have seen in the past that old Directive left number of ambiguities requiring even Court of Justice of the European Union (CJEU) to issue interpretations of its provisions in several judgments. In its judgment in the case Club Tour Court of Justice interpret that term 'pre-arranged combination' in provisions of the old Directive necessarily covers cases where the combination of tourist services is the result of the wishes expressed by the consumer up to the moment when the parties reach an agreement and conclude the contract ${ }^{2}$. In German and Czech national laws such situations were not considered to be pre-arranged commination. Case law of the CJEU on the provisions of the old Directive should also be applicable to the provisions of the new Package Travel Directive where appropriate.

Table 1. Timeline of the new Package Travel Directive

\begin{tabular}{|l|l|l|l|}
\hline $\begin{array}{l}\text { Enactment of the } \\
\text { Directive }\end{array}$ & $\begin{array}{l}\text { Entry into } \\
\text { force }\end{array}$ & $\begin{array}{l}\text { Deadline for } \\
\text { transposition }\end{array}$ & $\begin{array}{l}\text { Deadline for application of } \\
\text { transposed provisions }\end{array}$ \\
\hline $\begin{array}{l}16 \text { November Decembe } 1 \text { January 2018 } \\
2015\end{array}$ & $\begin{array}{l}16 \text { July } 2018 \\
2015\end{array}$ & & \\
\hline
\end{tabular}

Source: authors according to the new Package Travel Directive (2015/2302/EU)

Member states of the EU have produced variety of different solutions in transposition of the provisions of the old Directive into their national laws. Due to the different level of harmonization the new Package Travel Directive shall reduce this variety to a certain extent. The EU latest Member country - Croatia transposed provisions of the old Directive into section 24 of its Civil Obligations Act (ZOO). This paper inter alia analyses normative possibilities for transposition of the new Directive in Croatian Civil Obligations Act.

\section{ECONOMIC IMPORTANCE OF PACKAGE TRAVEL MARKET IN THE EUROPEAN UNION FROM THE STANDPOINT OF THE NEW PACKAGE TRAVEL DIRECTIVE}

The EU's travel market encompasses 1.8-million business which employ 5.2\% of the total workforce (European Commission, 2013). Majority of them are in the form of small and medium enterprises (SME). In some countries like Croatia there is substantial share of private accommodation in overall capacity. Majority of private accommodation in Croatia is operated by SME's (Vlahov, Vuletić, 2016). The travel market has been transformed by the liberalization of the airline sector, leading to cheaper and more accessible flight tickets (European Commission, 2013). Travel, tourism and related sectors account for around $10 \%$ of the EU's gross domestic product (GDP). The EU is the world's number one tourist

\footnotetext{
2 Issue of scope of the term 'pre-arranged combination' in the text of the new Package Travel Directive was determined in accordance with European Court of Justice ruling in the Club Tour case (new provisions now cover and customized packages).
} 
destination. Aforementioned summarized data clearly and conclusively demonstrates that economic importance of the EU's travel package market is substantial. This conclusion has even stronger meaning for EU Member countries in which tourist sector contributes in the overall economy more than EU average (e.g. Greece, Croatia, Austria and Spain) Therefore, legislative grey area in the package travel should be reduced to minimum. Although $23 \%$ of EU travellers still purchase traditional, pre-arranged packages, more and more either buy different parts of their trips separately (54\% of Europeans who took a holiday in 2011) or buy customized holidays, which are put together by one or more commercially linked traders to suit their needs and preferences.

Chart 1. Share of various forms of travel arrangements in the EU (in 2011)

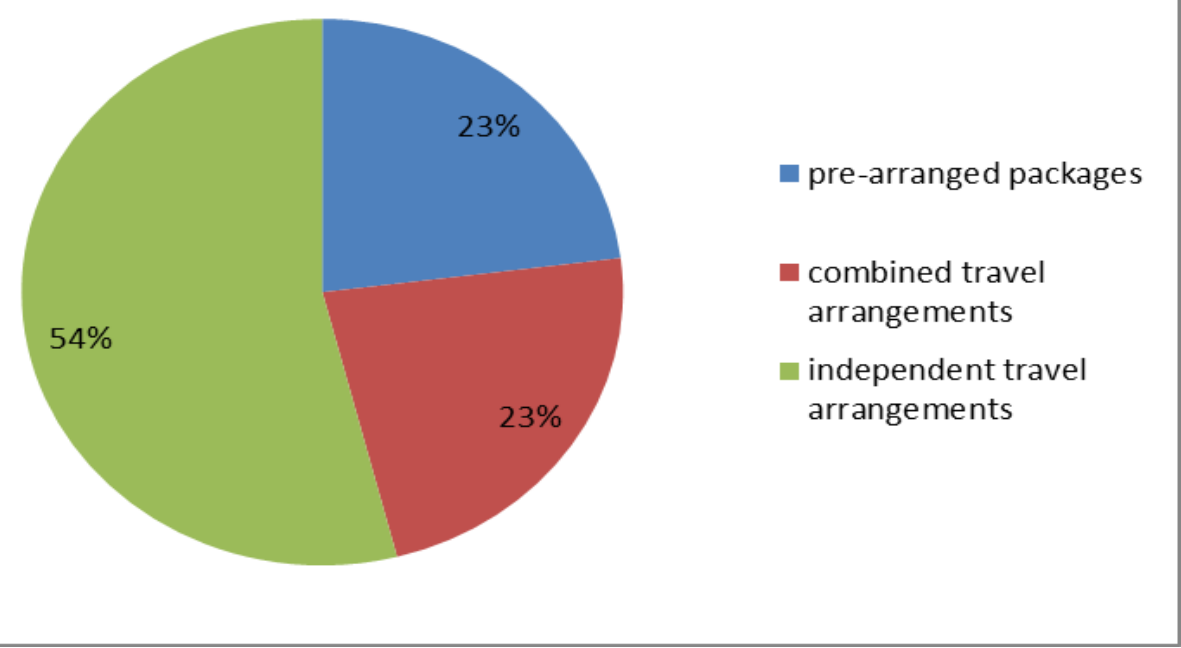

Source: European Commission (2013: 5)

The European Commission estimates that under new Package Travel Directive almost 120 million travellers buying combined travel arrangements will be protected, which was not the case under the old (existing) EU rules. Furthermore, Commission estimates that new rules will reduce damages to consumers by about $€ 430$ million a year (European Commission, 2016). The European Federation of Travel Agents and Tour Operators Associations (ECTAA) welcomed the initiative of the European Commission to modernize the existing legislation in its Position paper (ECTAA, 2013). It is important to notice that new rules will have an effect on global tourist market since significant share of travels covered under the scope of the new Package Travel Directive is directed to non-EU destinations. 


\section{SCOPE AND LEVEL OF HARMONIZATION OF THE NEW PACKAGE TRAVEL DIRECTIVE}

\subsection{Scope of the new Package Travel Directive}

Scope of the new Package Travel Directive is substantially wider than the scope of the old Directive. The new Package Travel Directive applies to packages offered for sale or sold by traders to travellers and to linked travel arrangements facilitated by traders for travellers. Consequently, new Directive covers pre-arranged packages, customised packages and linked travel arrangements. The old Package Travel Directive covered only pre-arranged travel arrangements ${ }^{3}$.

In the new Package Travel Directive 'package' now means a combination of at least two different types of travel services for the purpose of the same trip or holiday, if:

- those services are combined by one trader, including at the request of or in accordance with the selection of the traveller, before a single contract on all services is concluded; or

- irrespective of whether separate contracts are concluded with individual travel service providers, those services are: purchased from a single point of sale and those services have been selected before the traveller agrees to pay; offered, sold or charged at an inclusive or total price; advertised or sold under the term 'package' or under a similar term; combined after the conclusion of a contract by which a trader entitles the traveller to choose among a selection of different types of travel services; or purchased from separate traders through linked online booking processes where the traveller's name, payment details and e-mail address are transmitted from the trader with whom the first contract is concluded to another trader or traders and a contract with the latter trader or traders is concluded at the latest 24 hours after the confirmation of the booking of the first travel service.

Travel service under new Directive covers following: carriage of passengers; accommodation which is not intrinsically part of carriage of passengers and is not for residential purposes; rental of cars and other motor vehicles; any other tourist service not intrinsically part of a travel service. However, 'any other tourist services' are not covered under the definition of the package if they do not account

\footnotetext{
3 'Package' for the purpose of the old Package Travel Directive covered only pre-arranged combination of not fewer than two of the following (when sold or offered for sale at an inclusive price and when the service covers a period of more than twenty-four hours or includes overnight accommodation): transport, accommodation and other tourist services not ancillary to transport or accommodation and accounting for a significant proportion of the package.
} 
for a significant proportion of the value of the combination and are not advertised as and do not otherwise represent an essential feature of the combination or are selected and purchased only after the performance of a travel service has started.

Under individual travel service new Directive implies following services: services purchased from a single point of sale and those services that have been selected before the traveller agrees to pay, offered, sold or charged at an inclusive or total price; services advertised or sold under the term 'package' or under a similar term; services combined after the conclusion of a contract by which a trader entitles the traveller to choose among a selection of different types of travel services or purchased from separate traders through linked online booking processes where the traveller's name, payment details and e-mail address are transmitted from the trader with whom the first contract is concluded to another trader or traders and a contract with the latter trader or traders is concluded at the latest 24 hours after the confirmation of the booking of the first travel service.

The new Package Travel Directive still does not apply to:

- packages and linked travel arrangements covering a period of less than 24 hours unless overnight accommodation is included;

- packages offered, and linked travel arrangements facilitated, occasionally and on a not-for-profit basis and only to a limited group of travellers;

- packages and linked travel arrangements purchased on the basis of a general agreement for the arrangement of business travel between a trader and another natural or legal person who is acting for purposes relating to his trade, business, craft or profession.

\subsection{Level of the harmonization of the new Package Travel Directive}

The new Package Travel Directive is Directive of predominantly maximum harmonization in contrast to the old Directive, which required only minimum harmonization. Maximum harmonization basically means that Member states have fewer regulatory choices in transposition of the provisions of the Directive into their national law. Member states cannot maintain or introduce in their national law provisions diverging from those laid down in Directive, including more or less stringent provisions, which would ensure a different level of traveller protection.

Directives of minimum harmonization leave to Member states wider area for regulatory choices so that they are free to introduce stringer provisions than the minimum standard required by the directive. The old Package Travel Directive required only minimum harmonization. The method of minimum harmonization was clearly sub-optimal for this subject matter. Various ambiguities emerged from the harmonization of national laws with provisions of the old Directive. One of the 
best examples is unclear formal requirements ${ }^{4}$ for the package travel contract (Schulte-Nölke and Meyer-Schwickerath, 2008). Even the term 'consumer' was defined differently than standard concept of EU Consumer Protection Law. The European Court of Justice resolved variety of ambiguities emerging from the provisions of the old Directive. Most relevant case law, in addition to previously mentioned judgment in case Club Tour, are rulings in the Rechberger and ABS Finland cases and judgment in joined cases Pammer and Hotel Alpenhof.

Naturally the new Directive is imperative in nature and addressed to all Member States. Any contractual arrangement or any statement by the contractual parties, which directly or indirectly waives or restricts the rights conferred on travellers pursuant to this Directive or aims to circumvent the application of this Directive shall not be binding on the traveller.

\section{PACKAGE TRAVEL CONTRACT}

The package travel contract is defined in the new Directive as contract on the package as a whole or, if the package is provided under separate contracts, all contracts covering travel services included in the package. Definition of the term 'package' under the new Directive has been explained in third chapter of this paper.

Contractual parties of the package travel contract are called traveller and trader. Traveller is any person who is seeking to conclude a contract, or is entitled to travel on the basis of a contract concluded. Trader is any natural person or any legal person, irrespective of whether privately or publicly owned, who is acting, including through any other person acting in his name or on his behalf, for purposes relating to his trade, business, craft or profession in relation to package travel contract. Trader can be acting in the capacity of organizer, retailer, and trader facilitating a linked travel arrangement or as a travel service provider. Generally subject is to be considered a trader irrespective of his position in the distribution chain.

Prior to the conclusion of the package travel contract traveller has to be provided with following information:

- the main characteristics of the travel services;

- the trading name and geographical address of the organizer and, where applicable, of the retailer, as well as their telephone number and, where applicable, e-mail address,

\footnotetext{
${ }^{4}$ The old Package Travel Directive uses following ambiguous requirement for the form of the package travel contract: 'in writing or such other form as is comprehensible and accessible to the consumer' (Art. 4).
} 
- the total price of the package inclusive of taxes and, where applicable, of all additional fees, charges and other costs or, where those costs cannot reasonably be calculated in advance of the conclusion of the contract, an indication of the type of additional costs which the traveller may still have to bear,

- the arrangements for payment, including any amount or percentage of the price which is to be paid as a down payment and the timetable for payment of the balance, or financial guarantees to be paid or provided by the traveller,

- the minimum number of persons required for the package to take place and the time limit before the start of the package for the possible termination of the contract if that number is not reached,

- general information on passport and visa requirements, including approximate periods for obtaining visas and information on health formalities, of the country of destination;

- information that the traveller may terminate the contract at any time before the start of the package in return for payment of an appropriate termination fee, or, where applicable, the standardized termination fees requested by the organizer,

- information on optional or compulsory insurance to cover the cost of termination of the contract by the traveller or the cost of assistance, including repatriation, in the event of accident, illness or death.

The main characteristics of the travel services include: travel destination(s), itinerary and periods of stay, with dates and, where accommodation is included, the number of nights included; the means, characteristics and categories of transport, the points, dates and time of departure and return, the duration and places of intermediate stops and transport connections. Where the exact time is not yet determined the organizer and, where applicable, the retailer shall inform the traveller of the approximate time of departure and return. The main characteristics of the travel services also include: location, main features and, where applicable, tourist category of the accommodation under the rules of the country of destination; the meal plan; visits, excursion(s) or other services included in the total price agreed for the package; where it is not apparent from the context, whether any of the travel services will be provided to the traveller as part of a group and, if so, where possible, the approximate size of the group; where the traveller's benefit from other tourist services depends on effective oral communication, the language in which those services will be carried out; and whether the trip or holiday is generally suitable for persons with reduced mobility and, upon the traveller's request, precise information on the suitability of the trip or holiday taking into account the traveller's needs.

The new Directive contains in Annexes A and B standardized information forms for package travel contracts that should be visible to travellers. This standardized 
information forms informs travellers that they will benefit from all EU rights applying to packages and encompasses, where possible, hyperlinks to key rights under the Directive.

Example 1. Selection from of the standard information form for package travel contracts

Standard information form for package travel contracts where the use of hyperlinks is possible

The combination of travel services offered to you is a package within the meaning of Directive (EU) 2015/2302.

Therefore, you will benefit from all EU rights applying to packages. Company XY/companies XY will be fully responsible for the proper performance of the package as a whole.

Additionally, as required by law, company $\mathrm{XY} /$ companies $\mathrm{XY}$ has/have protection in place to refund your payments and, where transport is included in the package, to ensure your repatriation in the event that it becomes/they become insolvent.

More information on key rights under Directive (EU) 2015/2302 (to be provided in the form of a hyperlink).

Source: Annex I, Part A of the new Package Travel Directive (2015/2302/EU)

The package travel contracts should be stipulated in plain and intelligible language and, in so far as they are in writing, legible. At the conclusion of the package travel contract or without undue delay thereafter, the trader shall provide the traveller with a copy or confirmation of the contract on a durable medium. The traveller shall be entitled to request a paper copy.

The package travel contract under the new Directive has to contain (essentialia negotii):

- any special requirements of the traveller which the organizer has accepted,

- information that the organizer is responsible for the proper performance of all travel services included in the contract and that he is obliged to provide assistance if the traveller is in difficulty,

- the name of the entity in charge of the insolvency protection and its contact details, including its geographical address, and, where applicable, the name of the competent authority designated by the Member State concerned for that purpose and its contact details,

- the name, address, telephone number, e-mail address and, where applicable, the fax number of the organizer's local representative, of a contact point or of another service which enables the traveller to contact the organizer quickly and communicate with him efficiently, to request assistance when the traveller is in difficulty or to complain about any lack of conformity perceived during the performance of the package,

- information that the traveller is required to communicate any lack of conformity which he perceives during the performance of the package, 
- where minors, unaccompanied by a parent or another authorized person, travel on the basis of a package travel contract which includes accommodation, information enabling direct contact with the minor or the person responsible for the minor at the minor's place of stay,

- information on available in-house complaint handling procedures and on alternative dispute resolution (ADR) mechanisms,

- information on the travellers right to transfer the contract to another traveller

The burden of proof as regards compliance with the information requirements will always be on the trader.

Traveller can before the start of the package, after giving a reasonable notice on a durable medium, transfer the package travel contract to a person who satisfies all the conditions applicable to that contract. Notice given at the latest seven days before the start of the package shall in any event be deemed to be reasonable. However, in the case of transfer of the contract to another traveller both of them are jointly and severally liable to the trader for the cost of the transfer and due balance. Trader can charge additional costs for the transfer if they can be considered reasonable.

After the conclusion of the package travel contract, prices may be increased only if the contract expressly reserves that possibility and states that the traveller is entitled to price reduction (in that event the package travel contract shall state how price revisions are to be calculated). Price increases shall be possible exclusively as a direct consequence of changes in: the price of the carriage of passengers resulting from the cost of fuel or other power sources; level of taxes or fees on the travel services included in the contract imposed by third parties not directly involved in the performance of the package (including tourist taxes, landing taxes or embarkation or disembarkation fees at ports and airports) or the exchange rates relevant to the package. In any case if trader increases the price more than $8 \%$ traveller can terminate the contract without paying a termination fee.

Trader may not unilaterally change package travel contract terms (other than the price under aforementioned conditions) unless: the organizer has reserved that right in the contract; the change is insignificant and the organizer informs the traveller of the change in a clear, comprehensible and prominent manner on a durable medium. The traveller may within a reasonable period specified by the trader accept the proposed change or terminate the contract without paying a termination fee.

The traveller may terminate the package travel contract at any time before the start of the package in which case he may be required to pay an appropriate and justifiable termination fee. In the event of unavoidable and extraordinary circumstances occurring at the place of destination or its immediate vicinity and significantly affecting the performance of the package, or which significantly affect the carriage of passengers to 
the destination the traveller shall have the right to terminate the package travel contract before the start of the package without paying any termination fee. In aforementioned event traveller shall be entitled to a full refund of any payments made for the package but excluding any additional compensation.

If, after the start of the package, significant elements of the package cannot be provided as agreed, suitable alternative arrangements will have to be offered to the traveller at no extra cost. Travellers may terminate the contract without paying any termination fee, where services are not performed in accordance with the contract and this substantially affects the performance of the package and the organizer fails to remedy the problem. Travellers are also entitled to a price reduction and/or compensation for damages where the travel services are not performed or are improperly performed.

The organizer may terminate the package travel contract and provide the traveller with a full refund of any payments made for the package. Furthermore the trader shall be considered liable for additional cost caused by termination. Exception to this liability for additional compensation are the following situations: when the number of persons enrolled for the package is smaller than the minimum number stated in the contract and the organizer notifies the traveller of the termination of the contract within the period fixed in the contract, but not later than: 20 days before the start of $\mathrm{n}$ the case of trips lasting more than six days; seven days before the start of the package in the case of trips lasting between two and six days; 48 hours before the start of the package in the case of trips lasting less than two days. The organizer will never be liable for additional cost caused by termination in situations when prevented from performing the contract because of unavoidable and extraordinary circumstances and notifies the traveller of the termination without undue delay before the start of the package.

The organizer is responsible for the performance of the travel services included in the package travel contract, irrespective of whether those services are to be performed by the organizer or by other travel service providers. It is very important to note there is always at least one trader who is liable for the proper performance of all the travel services included in the contract.

The trader is liable for any errors due to technical defects in the booking system which are attributable to him and, where the trader has agreed to arrange the booking of a package or of travel services that are part of linked travel arrangements, for the errors made during the booking process. A trader shall not be liable for booking errors which are attributable to the traveller or which are caused by unavoidable and extraordinary circumstances.

The organizer's insolvency protection has to be established in the form of security for the refund to the traveller. Travellers shall benefit of this insolvency protection 
regardless of their place of residence, the place of departure or where the package is sold and irrespective of the Member State where the entity in charge of the insolvency protection is located.

\section{LINKED TRAVEL ARRANGEMENTS}

Linked travel arrangement under new Directive are at least two different types of travel services purchased for the purpose of the same trip or holiday, not constituting a package, resulting in the conclusion of separate contracts with the individual travel service providers. They constitute a linked travel arrangement if a trader facilitates:

- on the occasion of a single visit or contact with his point of sale, the separate selection and separate payment of each travel service by travellers; or

- in a targeted manner, the procurement of at least one additional travel service from another trader where a contract with such other trader is concluded at the latest 24 hours after the confirmation of the booking of the first travel service.

The trader facilitating linked travel arrangements must provide security for the refund of all payments they receive from travellers insofar as a travel service which is part of a linked travel arrangement is not performed as a consequence of their insolvency. If such traders are the party responsible for the carriage of passengers, the security shall also cover the traveller's repatriation.

Provisions of the new Directive relating to the termination of the contract, right of withdrawal before the start of the performance and alteration of the price in package travel contract apply to the linked travel arrangements as well. Other provisions relating to package travel contracts in general are not applicable to linked travel arrangements. Therefore, new Directive stipulates obligation of a trader to inform traveller on this exclusion on standardized information forms contained in the Annexes.

Example 2 Selection from the standardized information form for travellers

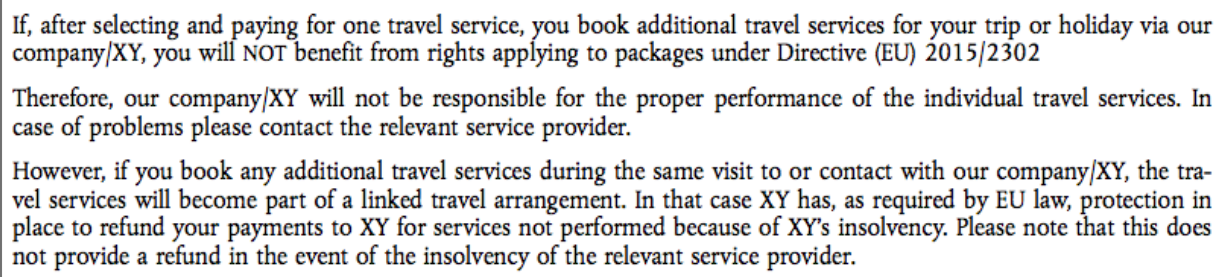
vel services will become part of a linked travel arrangement. In that case XY has, as required by EU law, protection in place to refund your payments to XY for services not performed because of XY's insolvency. Please note that this does not provide a refund in the event of the insolvency of the relevant service provider.

Source: Part A of the Annex II of the new Package Travel Directive $(2015 / 2302 / \mathrm{EU})$ 


\section{IMPLEMENTATION INTO TOURISM LAW OF MEMBER STATES: COMPARATIVE OVERVIEW AND STUDY OF NORMATIVE POSSIBILITIES IN CROATIA}

\subsection{Comparative legal overview in EU Member States}

Until the adoption of the old Directive package travel contract in majority of EU countries was unregulated or in the terminology of continental civil law unnominated contract (Gorenc et al, 2014: 1356-1365). Notable exception was Germany with an act regulating travel contracts in 1979 (Reisevertragsgesetz). Spain regulated travel contracts in 1963 within national legislation regulating to travel agencies (Reglemento que regula el ejercio da las actividades proprias de las agencias de viajes). Croatia regulated travel contracts prior to full membership in the EU.

In should be noted that the International Institute for the Unification of Private Law (standard abbreviation is UNIDROIT), distinguished international organization, prepared the International Convention on Travel Contracts in 1970. This Convention regulates travel contracts as 'organized travel contracts 'and 'intermediate travel contracts' in the more general manner than new Package Travel Directive. In principle the UNDROIT Convention sets lower standard of regulating than the new Directive but they are not mutually exclusive. UNIDROIT Convention is wider in scope than old Directive because it regulates intermediate travel contracts. However of 28 EU Member states only Belgium and Italy ratified the International Convention on Travel Contracts (UNIDROIT, 2015).

After the adoption of the old Directive EU Member States decided to transposed its provisions into their national laws by two general methods:

(1) by enacting special statute regulating travel contracts in particular,

(2) by enacting revisions into general civil law or national consumer protection law.

EU Member States that enacted particulars statutes on travel contracts are Ireland, Portugal, Finland and Sweden (Gorenc et al, 2014: 1356-1365). Other method is incorporating provisions of the Directive into general civil law or consumer protection legislature. Latter method was adopted by Germany, Austria, Portugal Belgium, Netherlands and Austria. Spain represents special case due its regulation of travel contracts within national rules relating to travel agencies.

In the transposition of the provisions of the new Package Travel Directive generally it would be reasonable to assume that each particular EU Member States will maintain current method. Germany will incorporate provisions of new Directive into its Civil Code (BGB). Sweden will adopt revisions to particular Act 
regulating travel contracts but probably also will have to adopt revisions of its general consumer protection law. However, since the provision of the old Directive are very specific and are targeting maximum harmonization in detailed manner transposition into national laws will be more demanding in comparison with old Directive. This could result that some of the Member States even decide to change method of adoption.

\subsection{Normative possibilities for transposition in the Croatian Tourism Law}

Croatia transposed provisions of the old Directive into section 24 of its Civil Obligations Act (ZOO) substantially prior to the full membership in the EU. Package travel contract (ugovor o organiziranju putovanja) is regulated in Art. 881-903. of Croatian Civil Obligations Act. Thus, Croatia is in the group of Members States that adopted method of transposition by enacting revisions of the general civil law. Croatian Act on the Provision of Tourism Services along with Civil Obligations Act represents national source of law for package travel contracts. Act on the Provision of Tourism Services defines term of package travel in Croatian law but primary source for this matter is Civil Obligations Act. Part of the Croatian Civil Obligations Act that deals with tourist contracts is inspired by UNDROIT International Convention on Travel Contracts (Pešutić, 2006; Petrović and Tepeš, 2005) despite the fact that Croatia is not party to the Convention. UNDROIT Convention was used as model law within the broader framework of soft law (Vuletić, 2011). After provisions that regulate package travel contract, national Civil Obligations Act contains provisions regulating intermediate travel contract (posrednički ugovor o putovanju) modeled after the UNDROIT Convention. Intermediate travel contract is regulated in the section 25 of the Croatian Civil Act. Provisions regulating package travel contract are legi generali in relation to provisions regulating intermediate travel contract.

Due to the maximum harmonization required by the new Package Travel Directive Croatia will have to adopt necessary legislative revisions until transposition deadline inspires. Most logical, reasonable and practical solution that is in line with existing national legal tradition would be revisions and amendments to Croatian Civil Obligations Act and Act on the Provision of Tourism Services.

Generally revision of the Civil Obligations Act could follow two principal normative solutions. First, to unify sections 24 and 25 into one section that would deal with package travel contracts and linked travel arrangements in accordance with provisions of the new Directive. This solution would require removal of intermediate travel contract as nominated contract from Croatian law. Second solution is to revise only section 24 of the Civil Obligations Act and to maintain intermediate travel contract modelled after UNDROIT Convention. In that case provisions regulating intermediate travel contract should be revised in accordance with requirements of the new Directive. Consequently, Croatian Act on the 
Provision of Tourism Services should also be revised in accordance with provisions of the new Package Travel Directive.

Standardized information forms for travellers contained in Annexes to the new Directive should also be annexed to future versions of Croatian Civil Obligations Act or alternatively to the revisions of to the Act on the Provision of Tourism Services.

Croatian Parliament enacted revisions to Civil Obligations Act in March 2018 which purpose was inter alia transposition of the new Package Travel Directive. Legislator opted for the first normative solution and removed specific provisions intermediate travel contracts modelled after UNDROIT Convention. Detailed and full harmonization modelled practically the level of translation was achieved with New of Croatian Act on the Provision of Tourism Services from 1 st of January 2018.

\section{CONCLUSION}

The primary purpose of this paper was to explore normative substance of the new Package Travel Directive and its perspective influence on the Croatian Tourism Law. New legislation will extend protection of the of the old 1990 EU Package Travel Directive to cover not only traditional package holidays, but also give clear protection to 120 million consumers who book other forms of combined travel. The new Directive broadens the concept of package and now will apply to different sorts of travel combinations: pre-arranged packages; customised packages and linked travel arrangements.

Internet as increasingly important medium for travel services produced surge of various forms of customized travel arrangements and rendered provisions of the old Directive obsolete to the needs modern tourist market. EU is the world's number one tourist destination. This information alone demonstrates substantially economic importance of the EU's travel package market. Thus it stand to reason that European Commission decided to construct new formal and normative framework in order to facilitate this somewhat spontaneous and informal process. We have seen in the past that provisions old Directive left number of ambiguities requiring even Court of Justice of the European Union (CJEU) to issue interpretations of its provisions in several of its judgments (most formative being ruling in the Club Tour case). The new Package Travel Directive requires maximum harmonization in contrast to the old Directive, which required only minimum harmonization.

Vast majority of travellers buying packages and linked travel arrangements are consumers within the meaning of the EU Consumer Protection Law. Thus, new 
Package Travel Directive should result in the enhancement of the consumer protection.

Process of transposition of the provisions of the new Package Travel Directive should be completed by January $1^{\text {st }} 2018$. Ii would be reasonable to assume that during this process each particular EU Member States will maintain current method of transposition for package travel contracts (e.g. Germany will incorporate provisions of new Directive into its Civil Code). However the provisions of the old Directive are very specific since they are targeting maximum harmonization in detailed manner. Thus, transposition into national laws will be more demanding in comparison with old Directive.

The EU latest Member country - Croatia transposed provisions of the old Directive into section 24 of its Civil Obligations Act (ZOO) and into Act on the Provision of Tourism Services. Thus, Croatia is in the group of Members States that adopted method of transposition by enacting revisions of the general civil law. Most logical, reasonable and practical solution that is in line with existing national legal tradition for new transposition process would be revision of the Croatian Civil Obligations Act.

Croatian enacted revisions to national Civil Obligations Act in March 2018 which purpose was transposition of the new Package Travel Directive. Legislator opted for the normative solution that required removal of specific provisions intermediate travel contracts modelled after UNDROIT Convention. In the beginning of same year full and detailed harmonisation was achieved by enactment of the New Act on the Provision of Tourism Services.

\section{REFERENCES}

1. Consolidated versions of the Treaty on European Union (TEU) and the Treaty on the Functioning of the European Union (TFEU), Official Journal of the European Union C 326 , 26/10/2012, p. $0001-0390$

2. Council Directive 90/314/EEC of 13 June 1990 on package travel, package holidays and package tours, Official Journal L 158, 23.6.1990, p. 59-64

3. Directive (EU) $2015 / 2302$ of the European Parliament and of the Council of 25 November 2015 on package travel and linked travel arrangements, amending Regulation (EC) No 2006/2004 and Directive 2011/83/EU of the European Parliament and of the Council and repealing Council Directive 90/314/EEC, Official Journal of the European Union L 326, 11.12.2015, p. 1-33

4. European Commission (2015) Factsheet: Stronger EU protection for package holidays, Brussels, available at (url): http://ec.europa.eu/consumers/consumer_rights/travel/documents/factsheet _new-package-travel_en.pdf [last accessed on June 18 2016] 
5. European Commission (2013): Communication from the Commission to the European Parliament, the Council, the European Economic and Social Committee and the Committee of the Regions: Bringing the EU Package Travel Rules into the Digital Age, Brussels, 9.7.2013 COM(2013) 513 final, available at (url): http://ec.europa.eu/justice/consumermarketing/files/com_2013_513_en.pdf [last accessed on June 18 2016]

6. European Travel Agents and Tour Operator's Associations ECTAA (2013) The Revision of the package travel Directive: ECTAA's Position Paper, Ref. BC13-086/4400, available at (url): http://www.ectaa.org/files/cms/bc13-086-4400--revised.pdf [last accessed on June 18 2016]

7. Gorenc, V., Belanić, L., Momčinović, H., Perkušić, A., Pešutić, A., Slakoper, Z., Vukelić, M., Vukmir, B. (2014) Komentar Zakona o obveznim odnosima. Zagreb: Narodne novine.

8. Gorenc, V., Pešutić, A. (2006) Razgraničenje organizatora i posrednika putovanja in Zbornik Pravnog fakulteta u Zagrebu, vol 56, 2006 special issue. Zagreb: Zagreb Law Faculty.

9. Petrović S., Tepeš, N., (2005) Materijalno pravni i međunarodno privatno pravni aspekti ugovora o organiziranju putovanja in Zbornik Pravnog fakulteta u Zagrebu, vol. 56, 6/2005. Zagreb: Zagreb Law Faculty

10. Schulte-Nölke, H., Meyer-Schwickerath, L. (2008) Package Travel Directive (90/314) in Schulte-Nölke, H., Twigg-Flesner, C., Ebers, M. EC Consumer Law Compendium

11. The Consumer Acquis and its transposition in the Member States. Munchen: Sellier

12. Vlahov, A., Vuletić, D. (2016) The role of stakeholders in creating new values of private sector accommodation in International OFEL Conference on Governance, Management and Entrepreneurship 2016 / Tipurić, Darko ; Mešin, Marina (eds.). Zagreb : CIRU - GOVERNANCE RESEARCH AND DEVELOPMENT CENTRE

13. Vuletić, D. (2011) Pravni aspekti Lisabonske strategije i budući izazovi razrada s motrišta pravne prirode mekog prava (soft law) in Zbornik Pravnog fakulteta u Zagrebu, Vol.61 No.3/2011. Zagreb: Zagreb Law Faculty.

14. Zakon o obveznim odnosima (Croatian Civil Obligations Act: ZOO, 2015), Narodne novine 35/05, 41/08, 125/11, 78/15, 29/18

15. Zakon o pružanju usluga u turizmu (Croatian Act on the Provision of Tourism Services: ZPUT, 2015) Narodne novine 68/07, 88/10, 30/14, $89 / 14,152 / 14$

16. Zakon o pružanju usluga u turizmu (New Croatian Act on the Provision of Tourism Services: ZPUT, 2017) Narodne novine 103/17 